\title{
The feasibility and farmer perception of true shallot seed technology in Sigi District, Central Sulawesi, Indonesia
}

\author{
HENI S.P. RAHAYU, MUCHTAR, SAIDAH \\ Central Sulawesi Assessment Institute of Agricultural Technology. Jl. Lasoso 62 Biromaru,Kabupaten Sigi, Central Sulawesi, Indonesia. \\ Tel. +62-451-482546. `email: sulistyawati79@gmail.com
}

Manuscript received: 30 October 2018. Revision accepted: 8 February 2019.

\begin{abstract}
Rahayu HSP, Muchtar, Saidah. 2019. The feasibility and farmer perception of true shallot seed technology in Sigi District, Central Sulawesi, Indonesia. Asian J Agric 3: 16-21. Shallot is one of the horticultural commodities that play a significant role in both the national and regional economies around Indonesia. A fluctuating supply of shallot influences the inflation level. Shallot production is currently facing many problems, including high production costs. The production cost mostly goes to expenses for labor and seed, while Indonesian shallot is mainly produced from the bulb seed. This high-cost production causes lower shallot competitiveness. Therefore, introduction of True Shallot Seed (TSS) technology, which lowers the cost of shallot seeds, could be an ideal option to improve the shallot competitiveness in Indonesia. However, the shallot farming feasibility and the farmer's perception of this technology are two critical aspects that need to be considered in the adoption of this new technology. This research aimed to study the potency of true shallot seed development in Central Sulawesi based on the TSS's farming feasibility and farmer perception of TSS. The research was conducted in Sigi District, Central Sulawesi. The results showed that the farming of shallot using TSS was feasible, and within 14.9 t.ha $^{-1}$ productivity, the Revenue-Cost Ratio was 3.15 while the Benefit-Cost Ratio was 2.15 . The perception was examined based on three aspects namely technical, economic, and social aspects. The results showed that farmers were interested in planting true seed of shallot based on its high productivity, lower production cost, and market acceptance of the product; while in the social aspect, the extension and farmer group's support still need to be improved for development of TSS.
\end{abstract}

Keywords: Central Sulawesi, perception, shallot, seed cost

\section{INTRODUCTION}

Shallots are one of the vegetable commodities that have high economic value in terms of meeting the national consumption, farmers' sources of income, and as one of the potential foreign exchange earners. Besides being used in cooking, shallot also can have health promoting properties. Shallot can be cultivated in a wide range of agroecosystems, from lowland to highland regions. In Sigi Regency, shallot is cultivated by farmers in the lowlands. Dolo and Sigi Biromaru sub-districts are among the shallot production centers in Sigi District. Bima and Tajuk are shallot varieties mainly cultivated by farmers in these two sub-districts.

Shallot production in Indonesia is commonly based on crops generated from bulb seeds. However, most farmers usually sell the bulbs immediately after harvest as they need immediate cash, in addition to their inability to store the bulbs safely in a large quantity. Consequently, there has been a shortage of blubs that are usually used as seeds at the peak of planting time. Furthermore, farmers are forced to buy bulb seeds in the market at a very high price, which in most cases, are transported from long distances such as East Java. Some farmers keep their own bulb seeds by tightening them into bunches and hang them for two to three months. This method is also used to break the seed dormancy problem. However, some bulbs decrease in quality with the storage time, especially if the storage system is not properly managed. In addition, the use of bulbs as planting materials can also promote diseases caused by pathogens such as viruses, fungi, bacteria, and nematodes (Currah and Proctor 1990).

For tackling all problems related to the use of bulb seed, a research effort was made to grow shallot from the true seed of shallot (TSS). This was a good option for the grower to avoid storage problems, since TSS can be stored for a longer time and less space is needed. Furthermore, fewer seeds are required and the TSS is easily handled, including its transportation to the farm. Shallot production using bulbs, need a high amount of seed of around 1 to 1.5 tons of bulb seed per hectare. While using true shallot seed, one would need only approximately $4-6 \mathrm{~kg}$ per hectare.

Another advantage of TSS is that shallot crops are grown from true seeds also have a lower seed cost. Since the cost for seeds from bulbs is the highest in shallot farming (Putter and Adiyoga 2013), the price of shallot bulb seed is an important consideration. In Central Sulawesi, the price range of bulb seeds is anywhere from IDR 25000 to IDR 60000, depending on the fluctuation of shallot bulbs price for consumption purposes. Brick and Basuki (2010) found that at the farmers' level, the use of TSS as planting material was cheaper than that of bulb seeds. Furthermore, the plant density in seedlings will determine which one is more costly, between TSS seedling and bulb seed. The cost of TSS seedlings from the variety Sanren, in the planting density of 75 plants/ $\mathrm{m}^{2}$ was cheaper than the cost of bulb seed, if the price of the bulb 
seed was IDR $10000 \mathrm{~kg}^{-1}$ or higher. In a planting density of 150 plants $/ \mathrm{m}^{2}$, however, the cost of TSS was cheaper than bulb seed only when the price of bulb seed was more than IDR $15000 \mathrm{~kg}^{-1}$. These results showed that the cost of bulb seed in Central Sulawesi is assumed to be higher than that of TSS. In addition to its lower cost, TSS also produces high yield with uniform bulb size under both highland and lowland conditions. These advantages would enable farmers to shift from the cultivation of shallot from bulb seed to TSS and can help them to grow a disease-free crop in new areas and reduce the production cost by half (Shimeles 2014).

True shallot seed is a new technology in Central Sulawesi. One consideration for developing this new technology is its economic feasibility. Even though shallot crops generated from TSS produce a higher production, farmers need to make sure that the new technology is feasible and profitable. Planting of true shallot seed needs additional treatment since it needs a seedling process similar to that of rice cultivation. The need for this extra work causes a longer production time and is more labor intensive. Also, the financial feasibility of shallot farming needs to be known to see whether it is feasible or not to be cultivated. The feasibility analysis needs to be conducted regarding its high risk of failure, as it is common with horticulture commodities. This study objective was to find out whether shallot farming using TSS is feasible or not, to provide incentives for shallot farmers. The result will serve as evidence to convince farmers to adopt the new technology and to make useful recommendations to develop new technology.

Another critical consideration is the farmer's perception of the new technology or innovation. Innovation can be described as ideas, ways, or objects that are perceived by someone as something new. According to Rogers (1983), the level of adoption of an innovation depends on the adopter's perception of the characteristics of technological innovation. The farmer's understanding of technological innovation requires mental readiness to adopt the technology that is useful and applied through a process of perception. Koster and Basuki (1991) stated that the adoption of a new technology recommended by researchers depends on many interrelated factors. The farmers' decision to adopt a crop cultivation technology is influenced by factors such as socio-cultural, economic, and biophysical aspects, and problems related to these aspects (e.g., capital, know-how, market uncertainty). Their choice is, thus, conditioned by what best fits their situation, thereby reducing risks as far as possible. In general, new technology can be rejected by farmers because the technology itself cannot help farmers to solve their problems. This means that to be adopted by farmers, new technology must be appropriately developed and meet the farmers need.

Since TSS is a new technology in Central Sulawesi, no study has been carried out so far about its feasibility and the farmer's perception of this technology. This research objective was to investigate the feasibility of the use of TSS in shallot farming and to know the farmer perception of TSS based on the three aspects namely technical, economic, and social. Both the TSS feasibility and farmer perception are important to make an effective recommendation to develop new technology.

\section{MATERIALS AND METHODS}

The study was conducted in Central Sulawesi Province of Indonesia. Specifically, the study focused on Dolo and Sigi Biromaru sub-district. These study areas were selected purposively, as they are shallot farming centers in Sigi District, Central Sulawesi. Both primary and secondary data were used in the study. The primary data was collected from the shallot farmers. Data were obtained through interviews involving randomly chosen 32 shallot farmers. A structured questionnaire was used to guide the data collection through personal interviews of household heads.

Furthermore, the collected data were tabulated and analyzed based on the research objectives. Secondary data dealt with the socio-economic conditions of the households and the study area. The secondary data was gathered from several sources including annual reports of local governments, the Indonesian Statistical Bureau, Indonesia Ministry of Agriculture, farmer associations and other relevant institutions.

The level of shallot farming income was calculated by calculating the costs incurred in shallot farming or also called production costs. The financial analysis included total revenue, total variable cost, gross margin, and net revenue based on the formula by Hendrayana (2017).

Total Revenue (TR) is the revenue from shallot production that was obtained from the sales of shallot bulbs. The shallot bulbs were sold to the fried shallot industry and in the market for household consumption. Total revenue of each farm was calculated as follows:

$$
\mathrm{TR}=\mathrm{PY}
$$

Where:

$\mathrm{TR}=$ total revenue from sales of output (shallot)

$\mathrm{P}=$ price of shallot per kilogram in Indonesian rupiah

$\mathrm{Y}=$ total volume of shallot in kilograms

Total Variable Cost (TVC) is the sum of the total cost of each of input variables used by farmers in shallot production (seed, labor, inorganic fertilizer, organic fertilizer, herbicide, pesticide) and was calculated using the following formula:

$$
T V C=\sum_{j=1}^{6} C_{j}=\sum_{j=1}^{6} P_{j} X_{j}
$$

Where;

$C_{j}=$ total cost of each input variable $\mathrm{j} . \mathrm{j}=1,2$...6. 1seed, 2-labor, 3-inorganic fertilizer, 4-organic fertilizer, 5herbicide, 6-pesticide.

$P_{j}=$ the product of the price (or cost) per unit of input $\mathrm{j}$ $\left(\mathrm{P}_{\mathrm{j}}\right)$ and the total volume of input $\mathrm{j}(\mathrm{Xj})$ used in the production of shallot. 
Gross margin (GM) is the amount left after deducting from the Total Revenue minus the Total Variable Cost.

$$
\mathrm{GM}=\mathrm{TR}-\mathrm{TVC}
$$

This is supposed to pay for the fixed input used in shallot production, as well as to provide returns to farmers for their labor and management, and for their risk-taking.

Net Revenue (NR) is the amount left after deducting from the Gross Margin the Total Fixed Cost or deducting from Total Revenue the sum of the total variable cost and total fixed cost. This is supposed to provide payment for fixed inputs used in the shallot production, as well as to give returns to farm owners for their labor and management (Kay and Edwards, 1999) and their risk-taking.

$$
\mathrm{NR}=\mathrm{GM}-\mathrm{TFC} \text { or } \mathrm{NT}=\mathrm{TR}-(\mathrm{TVC}+\mathrm{TFC})
$$

Fixed costs are the cost associated with the use of fixed assets and management. Fixed costs in this study included rent of the farming land. The study also included interest as one of the cost items and was calculated using the formula:

$$
\mathrm{IOC}=\text { Alit }
$$

Where;

IOC $=$ Interest on operating capital

$\mathrm{Al}=$ Total investment $/ 2 \mathrm{I}=$ interest rate per year $(9$ percent)

$\mathrm{T}=$ length of the crop production period, in month, (4 months)

Feasibility measurement used was the Revenue Cost Ratio (RCR). (RCR is used to indicate the relationship between revenue and cost of any project in monetary terms, while benefit cost ratio (BCR) shows the relationship of cost and benefit. Higher RCR or BCR indicates a higher return from production. Usually, the total cost is used for calculating RCR (Anjum and Barmon 2017).

$$
R C R=\frac{T R}{T C}
$$

Farmer perception was analyzed using Scoring method (Hendrayana 2014) as follows:

$$
\begin{aligned}
& \text { Score Value }=\frac{n i . s i}{N} \\
& \text { ni }=\text { Number of respondents at column } \mathrm{i}(\mathrm{i}=1,2,3 \ldots 4) \\
& \mathrm{si}=\text { Score of comment in } \mathrm{i}(\mathrm{i}=1,2,3 \ldots 4) \\
& \mathrm{N}=\text { Total number of the respondent }(32)
\end{aligned}
$$

\section{RESULTS AND DISCUSSION}

\section{Characteristics of shallot farmers}

\section{Age of the shallot farmer respondents}

Farmers in Sigi District were 39 years old on average (Table 1), which is generally a productive age. Farmers in the productive age will accept innovations easier than the older ones. Productive age allows farmers to improve their performance and increase productivity that leads to higher profits. Nurhapsa (2013) found that people have increased the ability to work along with the increase of age, but the ability to work declines at a certain age, as the age influences the maturity and physical ability of the respondents in managing a business.

\section{Educational attainment}

Education (formal and non-formal education) can play a vital role in changing the attitude, behavior, and mindset of the farmers. Through education, farmers can get information and new technology innovation, thereby affecting the quality of decision-making. Natawidjaja et al. (2008) reported that formal education level affects the productivity of labor and level of technology adoption. Low education levels can result in low levels of productivity. The higher the education level completed by the farmers, the easier they will understand and accept innovations delivered to them. Shallot farmers have an average of ten years of educational attainment or graduated from Junior High School (Table 1). Under this education level, farmers are expected to be easier to accept new technology.

\section{Shallot farming experience}

The average number of years of shallot farming experience was seven years. Nurhapsa (2013) stated that the accumulation of sufficient experience will make it easier for farmers to receive and choose innovation or technology suitable and appropriate for use in farming. With seven years shallot farming experience, farmers are expected to be wise in choosing technology.

\section{Household size}

The average household size of the shallot farmerrespondents was four members. Bigger households have higher living costs, and most farmers do not have other income sources aside from shallot farming. The high consumption cost reduces the farmer's opportunity to allocate funds for farming inputs as the technology recommends, especially, if the price of input is high. However, the farm size is essential because growing vegetables is labor-intensive farming. Small-scale vegetable farming such as shallot is based on family labor (Beshir and Nishikawa 2012).

\section{Farm size}

The small farm remains to be one of the constraints in improving the production capacity of the farms. The average size of shallot farms of the respondents was 0.62 ha (Table 1). Farm size affects innovation adoption as the more the lands are made available, the higher the production output and farmers' income.

In the development of the commodity, extensification of production outside Java, has been limited because of the non-availability of capital. To get a higher income, a larger farm that is balanced by optimum input application to increase the scale of business is needed (Kahn and Maki 1979; Bagi 1982). 
Table 1. Characteristics of respondents of 32 shallot farmerrespondents from Sigi District, 2018

\begin{tabular}{ll}
\hline Characteristics & Average value \\
\hline Age (years) & 39 \\
Education (years) & 10 (Junior High School) \\
Household size (person) & 4 \\
Farming experience (years) & 7 \\
Farm size (hectare) & 0.62 \\
\hline
\end{tabular}

Table 2. The feasibility of shallot farming using True Shallot Seed (TSS) in Sigi District, Central Sulawesi, 2018

\begin{tabular}{lc}
\hline Items & Total (IDR) \\
\hline Gross Income & \\
Quantity of onion $(\mathrm{kg})$ & 14,900 \\
Selling price $(\mathrm{Rp} / \mathrm{kg})$ & 15,000 \\
Total Revenue & $223,500,000$ \\
Cost & \\
Fixed Cost & $3,500,000$ \\
Land cost & 150,000 \\
Irrigation & $3,650,000$ \\
Total fixed cost & \\
Variable Cost & $12,000,000$ \\
Seed & $30,085,000$ \\
Labor & $2,970,000$ \\
Inorganic fertilizer & $4,106,000$ \\
Organic fertilizer & $2,250,000$ \\
Herbicide & $14,170,000$ \\
Insecticide & $65,581,000$ \\
Total variable cost & $1,080,400$ \\
Opportunity Cost of Operating Capital & $\mathbf{7 1 , 0 3 5 , 0 0 0}$ \\
Total Cost & $157,919,000$ \\
Gross Margin & $152,465,000$ \\
Net Revenue & 3.15 \\
Revenue/Cost & 2.15 \\
Benefit/Cost & \\
\hline
\end{tabular}

\section{The feasibility of shallot farming using True Shallot Seed (TSS)}

The feasibility of shallot farming using TSS is important to be known as one of considerations for the farmer to adopt the new technology, whether the new technology will be economically feasible or give profit to farmers. The result showed that shallot farming using TSS was feasible and profitable to do.

There are several steps or processes of shallot cultivation namely: land preparation, line-making, planting, fertilizing, managing of pest and plant diseases, weeding/grass clearing, harvesting, and post-harvest. Each cultivation process varies in cost. The farmer's choice of technology will define the cost. For example, in grass clearing (weeding), either chemical (herbicide spray) or manual method is used. The manual method entails higher labor costs as compared to the chemical/herbicide spray method. Weeding of grasses using herbicides needs only half-day of labor or four hours of work but manual weeding takes one or two days to finish work depending on the farm size. The cost of labor also includes meals and, sometimes, cigarettes. Herbicides are normally applied two times during a growing season; the first is in the land preparation stage and the second is one month after planting. Labor cost for harvesting includes the cost of uprooting, transporting from field to house or storage place, cleaning, and binding. Harvesting is counted by man-days or by the number of plant lines. In either two ways, conversion to the man-days system was practiced.

Since labor is needed in many shallot cultivation processes, the labor expense is included as a significant cost sector in shallot farming. In TSS farming, additional labor is only required for seedling preparation. The seedling cost was around ten man-days or Rp. 650000 (one man-days equals Rp. 65000). The additional seedling cost distinguishes TSS from the bulbs shallot farming. Meanwhile, the bulb seeds are planted directly in the farming land after the dormancy break during storage. The performance of shallot farming using True Shallot Seed was described in Table 2.

Based on Table 2, shallot farming using TSS was profitable and feasible to be cultivated with the Revenue and Cost Ratio of 3.15. Shallot farming using TSS is still new in Indonesia while in other countries TSS technology has already been widely used for shallot or onion. Shallot farming using TSS is profitable as proved by Hewavitharane et al. (2011) who found that onion farming using TSS had an RCR of 2.01. As the risk of horticulture farming is higher compared to cultivation of other commodities, the high $\mathrm{RC}$ ratio of this commodity is a crucial consideration. The high risk of more significant loss in horticulture is mere because of the high production cost. Another factor affecting the profitability is the price of shallot. At the time of study, the price of shallot was Rp. 15000 on average, which is good enough to support farmers' income and profits. However, the shallot price is not stable as with that of other commodities. This high fluctuated shallot price is affected by the availability of shallot in the field. The fluctuating price of shallot profoundly affects the shallot farming business using seeds from bulbs, since the cost for seeds from bulbs will increase when the price of bulbs is high. This will increase the cost of shallot farming, and consequently, the farmers will not be able to cultivate their land as they have not enough capital to afford the farming expenses.

\section{Farmer's perception on True Shallot Seed (TSS) technology}

Farmers' perception of technical, social, and economic aspects of TSS development was assessed based on the reasons stated by farmers. Perception was measured using a Likert scale. The decision of farmers to apply technology is mainly determined by internal factors within the farmer, including the attitude and purpose in conducting farming. The attitude of farmers, in this case, is very dependent on the characteristics of the farmers, which includes socioeconomic characteristics, and aspects related TSS technology, i.e., technical, economic, and social aspects. Generally, the goal of farmers in carrying out their farming business is to increase the family income. The low level of technology adoption by farmers is influenced by many factors, including the lack of capital, high input prices, and low output prices (Sugandi dan Astuti 2012). 
Table 3. Farmer perception on True Shallot Seed, 32 farmerrespondents from Sigi District, 2018

\begin{tabular}{lc}
\hline Aspects & Total score \\
\hline Technical aspects & \\
$\quad$ Application of TSS technology & 2.563 \\
Access to technology information & 2.250 \\
$\quad$ Access to production inputs & 2.188 \\
Economic aspects & \\
$\quad$ Decrease of production cost & 3.031 \\
$\quad$ The suitability between the cost of technology & \\
change and profitability & \\
& \\
$\quad$ Marketing of product & 3.125 \\
Social aspects & 3.094 \\
$\quad$ Farmer's knowledge & \\
$\quad$ The liveliness of farmer group & 2.094 \\
The support of public services & 2.813 \\
& 2.781 \\
\hline
\end{tabular}

In general, farmers are interested in using TSS. Among all aspects considered, the economic aspect had the highest value of tendency or positive attitude from farmers (Table 3 ). On the economic aspect, the statement that the benefits of using TSS are commensurate with the cost of changing technology had the highest value. Based on what was seen in the implemented demonstrations, the farmers assessed that the costs incurred to change the conventional bulb seed technology into the TSS are commensurate with the benefits earned so that it is worth trying.

From the marketing side, there was no problem with the bulbs produced from TSS. Physically, there was no difference between bulbs from TSS and those from bulb seed. The bulb size and shape of the two seed sources were the same; therefore, it is acceptable by the market. Bulbs from TSS can be divided to have a size that fits the farmers and market preferences. Meanwhile, the color of shallot will depend on the variety. Another consideration in the economic aspect that received a positive response from the respondents was the decrease in production costs, especially the price of TSS that was quite more affordable as compared to that of seeds from bulbs. The lower price of TSS saved up to $40 \%$ of seed production cost expensed by the farmers, considering that the price of seeds is costly, around Rp. 25000 to Rp. 50000 per kg. Seeds from bulbs will require additional cost for transportation and storage.

The present study results are like those of Brink and Basuki (2012), who stated that the introduction of true shallot seed could be an option to improve competitiveness of Indonesian shallot production, and the recently developed true shallot seed cultivars are of high yielding, short duration, and good quality for the local market, which has increased the feasibility of true shallot seed production. Alfu et al. (2013) also indicated that there are many shallot cultivars in Indonesia with a varying degree of seed production potency, morphological traits, and yield, where such variations also indicate high genetic variations for the flowering date and resistance to pests and pathogens. The existence of these high-yielding shallot varieties with additional superior traits will reduce the risk of yield loss in shallot farming.
One of the social aspects that received positive responses was the liveliness of the farmer group. Farmer groups are a means of gaining support in the form of knowledge or skills as well as physical support from the government because, through these groups, the farmers' activities are accommodated. However, farmers' knowledge of TSS technology is still low, which necessitates extensive dissemination of technology to increase the farmer's understanding of the technology, which then allows them to be interested in adopting the technology. Supporting infrastructure facilities are also considered by farmers in adopting new technologies, including locally available production facilities.

From the technical aspect, farmers still have a limitation in TSS cultivation technology. Therefore, extensive dissemination of the TSS is urgently required. Furthermore, as a new thing, farmers even do not know the places to get production facilities, including TSS seeds. Currently, TSS technology is still at the level of Central Sulawesi Assessment Institute of Agricultural Technology (AIAT) researchers; thus, this technology needs to be more expanded, especially to the extension agents who can guide farmers directly and continuously in using this technology.

In conclusion, shallot cultivation using TSS was found profitable in the study area. It was economically beneficial and feasible to be managed with an R/C of 3.15. Perception of farmers in Sigi Regency on TSS was positive regarding three aspects, namely economic, social, and technical. Furthermore, TSS products can be accepted by the market. From a social aspect, infrastructure facilities and the existence of farmer groups supported the development of TSS while the knowledge of farmers about TSS application needs to be improved. The study results necessitate more extensive dissemination to improve the knowledge of farmers and extension workers about TSS through demonstration plots in the farming level.

\section{ACKNOWLEDGEMENTS}

The authors are grateful to Dr. Andi Baso Lompengeng Ishak as the Head of Central Sulawesi Assessment Institute for Agricultural Technology (AIAT), Indonesia for supporting the study.

\section{REFERENCES}

Alfu L, Endang S, Arif W. 2013. Morphogenetic variation of shallot (Allium cepa L. Aggregatum group). Agric Sci 16 (2):1-11.

Anjum A, Barmon BK. 2017. Profitability and comparative advantage of onion (Allium cepa) production in Bangladesh: An Economic Study in Some Selected Areas. Agriculturists 15(2): 66-78.

Bagi, FS. 1982. A Relationship between farm size and technical efficiency in West Tennessee Agriculture. South J Agric Econ 14:139-144.

Beshir B, Nishikawa Y. 2012. Cost-benefit analysis of small-scale onion and tomato farming in Melkassa area: Central Rift Valley of Ethiopia. Trop Agric Develop 56 (4): 143-150.

Brink VL and Basuki RS. 2010. Improvement of shallot supply chains; Dissemination of shallot production technology of True Seed Shallot (TSS) through conducting farmers' field days on participatory demplots. Lelystad, Netherlands. 
Brink VL, Basuki RS, 2012. Production of True Seed Shallots in Indonesia. International Society for Horticultural Science. ISHS Acta Horticulturae, 958: 115-120.

Currah L, Proctor FJ. 1990. Onions in tropical regions. Bulletin No. 35 Natural Resource Institute, ODA, Kent, UK

Hendrayana R. 2014. Data analysis of assessment. Indonesian Agency for Agricultural Research and Development (IAARD) Press. Jakarta.

Hendrayana R. 2017. Perception and adoption of technology. Theory and Practice Measurement. Indonesian Agency for Agricultural Research and Development (IAARD) Press. Jakarta.

Hewavitharane HVC, Weerahewa J, Warnakulasooriya HU. 2010. An assessment of financial viability of big onion seed production in Matale District. Trop Agric Res 22 (1): 107-112.

Kay RD, Edwards W M. 1999. Farm Management (4th ed.). The McGraw-Hill Companies, Inc., New York, USA.

Khan MH, Maki DR. 1979. Effect of farm size on economic efficiency: The Case of Pakistan. Amer J Agric Econ 61: 64-69.

Koster W, Basuki R. 1991. Identification and farmer's problems as basis for development of appropriate technology: A case study on shallot production development. ISHS Acta Horticulturae, 270:
International Symposium on Horticultural Economics in Developing Countries.

Natawidjaya R, Djuwendah E, Mukti G. 2008. Socioeconomic effect in SRI system for rice farmer in Tasikmalaya District. Padjajaran University, Sumedang, Indonesia.

Nurhapsa. 2013. Technical Efficiency Analysis and Farmer Risk Behavior as well as its Effects on the Superior Variety Application in Potato Farming in Enrekang Regency, South Sulawesi Province. [Dissertation]. Bogor Agriculture University, Bogor.[Indonesian].

Putter H, Adiyoga W. 2013. Improving the shallot and hot pepper cultivation systems in the coastal plain of Northern Java. Veg Impact Report. Wageningen UR. The Netherlands.

Rogers, EM. 1983. Diffusion of innovations. The Free Press. Harvard Business. London.

Shimeles, A. 2014. The performance of True Seed Shallot Lines under different environments of Ethiopia. J Agric Sci 59 (2): 129-139

Sugandi D, Astuti UP. 2012. Perception and farmer adoption to new varieties in irrigated land of Bengkulu Province. Available from: http://pse.litbang.pertanian.go.id/ind/pdffiles/Pros_2012_07A_MP. Pdf. [Accessed 27 September 2018]. 